\title{
Some Problems of Digital Environment Influence on the Content of Civil Law Object and Subject Categories
}

\author{
Irina D. Kuzmina (part 1) \\ and Inna S. Bogdanova (part 2)* \\ Siberian Federal University \\ 79 Svobodny, Krasnoyarsk, 660041, Russia
}

Received 21.01.2019, received in revised form 26.02.2019, accepted 06.03.2019

The article is devoted to the study of problems arising as a result of the impact of modern digital environment on such traditional categories of civil law as object and subject of legal relations. As a result of the ongoing processes of digitization of social relations, a specific means of payment that is electronic money, the nature of which remained unresolved by the legislator, appeared in the current legislation. An analysis of existing approaches has led to the conclusion that the doctrine usually qualifies electronic money as a type of obligation, money law, a requirement expressed in electronic form. They are independent objects of civil rights that do not coincide with non-cash money and with "digital money" (cryptocurrency). Furthermore, the article concluded that, besides the change in the existing approaches to the objects of civil legal relations, the Internet environment has led to the transformation of the existing ideas about their subjects, as a result of which the accepted definition of this civil law category becomes ineffective. It is argued that the Internet space contains subjects with some specific features, such as unlimited composition; a high degree of anonymity; extraterritoriality of action; self-management and self-organization. These features do not allow the effective use of civil law to resolve conflicts. The arising difficulties have been studied using the example of the participation of public legal entities and their officials in the Internet.

Keywords: digital environment, Internet resources, electronic cash, non-cash funds, digital money, cryptocurrency, virtual personality, subject of law on the Internet, public formations, head of state.

Research area: law.

Citation: Kuzmina, I.D., Bogdanova, I.S. (2019). Some problems of digital environment influence on the content of civil law object and subject categories. J. Sib. Fed. Univ. Humanit. soc. sci., 12(3), 393-409. DOI: 10.17516/1997-1370-0401.

(C) Siberian Federal University. All rights reserved

* Corresponding author E-mail address: kuzmina-58@mail.ru; bogdanov_rabota@mail.ru

ORCID: 0000-0003-0732-292 (Bogdanova)

This work is licensed under a Creative Commons Attribution-NonCommercial 4.0 International License (CC BY-NC 4.0). 
Introduction. The rapid development of information technologies, electronic means and resources of the Internet in the modern society has led not only to the scientific and technological revolution, but also qualitatively changed the nature and content of human activity. Such transformations have become the subject of numerous studies and publications, but the question of whether the digital environment is capable of influencing the law, its concepts and categories, still remains open. At the same time, the current state of civil law and the practice of its application suggest that the main civil law categories have been and continue to be influenced by information technologies, undergoing fundamental transformations, as a result of which traditional methods and methods of civil law regulation become less effective.

This is most clearly reflected in the content of civil law object and subject categories. In the first case, it is about electronic cash used in e-commerce, in the second case it is about changing the category of a legal entity and the impossibility of its proper identification when making transactions and offenses on the Internet.

\section{Part 1. Legal regulation of the use of electronic money}

Legal regulation of e-commerce is characterized by multidimensionality. However, there is no doubt that the economic and legal basis of its existence is electronic money (e-money), used as a payment instrument.

The regulation of e-money legal regime is carried out outside the Civil Code of the Russian Federation (hereinafter all references to legal acts are given by the law reference service Consultant Plus. Accessed on December 1, 2018. http: www. consultant.ru), which does not mention their existence either in the rules on objects of civil rights, where, as is known, cash and non-cash funds are presented, or in the rules on the performance of obligations, on certain types of obligations, including settlement relations. The regulatory basis for the use of e-money to fulfil monetary obligations in the field of e-commerce is the federal law "On the National Payment System" No. 161FZ dated June 27, 2011 (hereinafter referred to as the NPS Law).

The current version of Article 3 of the NPS Law offers an extremely cumbersome definition of the concept of electronic money (e-money), "clearing" which to the degree of reflected essence, one can obtain its next version, namely the money that was previously provided by one party to another (obligator) to fulfill monetary obligations to third parties whose information is taken into account by the obligator without opening a bank account, and orders of the party who provided the money are carried out exclusively using electronic means of payment. The obligator organizing the 
fulfillment of a monetary obligation is the operator of electronic money, who transfers money without opening a bank account. Only a credit institution, including a non-bank credit institution, which is entitled to transfer funds without opening bank accounts and other banking operations associated with them (NCI) can be such a party. The same rule also defines the concept of electronic means of payment, the essence of which is that it is a tool that allows a client of a money transfer operator to make, certify and transfer orders for the purpose of making money transfers within the framework of applicable forms of cashless payments using information communication technologies, electronic media, including payment cards, as well as other technical devices.

The above definitions certainly give some idea of the phenomena of legal reality proposed in them, their relationship with each other: e-money is a kind of so-called "electronic money", because it is based on money that is provided for use without opening a bank account, information about which is stored in electronic form. The use of this "monetary value" is carried out by transferring it within the framework of applicable forms of cashless payments using information and communication technologies, electronic data carriers (electronic means of payment).

However, the NPS Law does not directly define the nature of e-money, their place in the system of civil rights objects, their correlation with the category of non-cash money, does not fix their value as a legal tender, which is absolutely necessary for the organization of certain types of obligations, bankruptcies and hereditary relationships.

The solution of these issues is undertaken in the doctrine. The most frequently considered options are the qualifications of e-money as a property right of claim (Kazachenok, 2017: 47-50) of "their holder to the operator for issuing a certain amount of cash or non-cash money" (Savel'ev, 2016) or, otherwise, a monetary claim to the obligator (issuer) expressed "in electronic form, which is transmitted when paying from the payer to the recipient" (Savel'ev, 2017: 136-153).

In the literature, property rights are understood as rights that possess features of "exchange value, ... which is transferable into money" (Gambarov, 1911: 595), i.e. a possibility to be evaluated in money, as well as their turnover, i.e. the ability to alienate (Pokrovsky, 2003: 238-239; Yakovlev, 2005: 53-59). In the literature, property rights include liability rights, some corporate rights, exclusive rights (Sukhanov, 2006: 400), property and inheritance rights (Lapach, 2003: 18-20). The allocation of such type of objects of civil rights as property rights, despite the generation of the controversial construction of the "right to right" (Gambarov, 1911: 578; Belov, 2001: 14-19), is due to the possibility of disposing them, recognizing them as an independent object of 
turnover (for example, see Article 93, 388, Paragraph 4 of Article 454, Article 824, 1233 of the Civil Code of the Russian Federation, etc.).

Defining e-money as a property right solves the problem of their qualification for the sphere of bankruptcy and inheritance relations, among the objects of which property rights are presented, but do not define the relationship of the category under consideration to objects that are legal means of payment, i.e. to money. It is generally accepted that in the sphere of civil legal relations, the main function of money is to be a means of payment, a means of paying off debt. The Civil Code of the Russian Federation considers the ruble to be a legal tender and establishes the rule that payments are made by cash and non-cash payments (Article 140). Cash payments are made in cash, noncash payments are made in a non-cash way through banks, other credit organizations by transferring funds with or without opening bank accounts (Article 861 of the Civil Code of the Russian Federation).

As is known, the traditional dispute about whether the Russian legislator refers only cash to money or non-cash too was resolved in the course of reforming the provisions of Article 128 of the Civil Code of the Russian Federation, from which the mention of money was excluded, and instead two different essences such as cash and non-cash money, which are different by location among the objects of civil rights, were allocated. Cash form a special group of things, specifically mentioned by Article 128 of the Civil Code of the Russian Federation, since they exist in the form of banknotes or coins issued by the Bank of Russia. Their legislator separates them from non-cash money. As noted by the Constitutional Court of the Russian Federation in the Resolution "On the case on the verification of constitutionality of the sixth and seventh parts of Article 115 of the Criminal Procedure Code of the Russian Federation in connection with the complaint of Gloria closed joint-stock company dated December 10, 2014 No. 31$\mathrm{P}$, "non-cash money being type of property, do not belong to things, and therefore cannot be an object of real rights in civil law sense; by their nature non-cash funds that exist in the form of a record on the lender's bank account (their owner) represent their obligation requirement for a certain amount to the credit institution in which the account is opened." This legal position reflects the general doctrinal idea of the legal nature of non-cash funds and their place in the system of civil rights: contrary to the assertion of the legislator, who attributed non-cash funds to the composition of other property, they exist in the form of "the right of the requirement to the bank for withdrawal (payment) on the first request of money (the right to money) fixed by means of accounting records maintained by a bank" (Novoselova, 2003), i.e. property right. 
Cashless funds, as well as cash, are money and have equal payment power, differing from each other "only in a form, but not in an essence. Moreover, they are interrelated and pass from one form to another" (Arzumanova, Artemov, Boltinova, 2016). This equality does not mean a complete coincidence of the legal regimes of cash and noncash money, in particular, different rules that determine the place of fulfillment of monetary obligations to pay cash and non-cash money have been established (Art. 316 of the Civil Code of the Russian Federation).

The Russian legislation separates the e-money funds from non-cash money funds, denoting, in particular, the specificity of their transfer (Article 7), and does not indicate their relationship to money and legal means of payment, which creates certain legal uncertainty. Meanwhile, as monetary funds expressed in national currency, they are provisionally provided to the obligator ("at the entrance") in order to fulfill monetary obligations to third parties ("at the exit"). It is logical to assume that e-money funds did not lose their payment function even during the period of being accounted by the obligator. In the economic turnover, they perform the function of a means of payment to third parties, which in fact is reflected by some acts of foreign law. Thus, Directive 2009/110/EC "On the establishment, operation and supervision of organizations involved in electronic money" indicates that electronic money is accepted as a means of payment (Khrustaleva, 2016: 5562). In this respect, the position of our Central Bank in the Information letter "On providing customers - individuals with information about the features of electronic money transfer services" dated March 11, 2016, No. IN-017-45/12 (together with the Memo "On electronic cash means") is rather telling, where it defined the concept of e-money funds in this way, "this is non-cash money in rubles or foreign currency, accounted for by credit institutions without opening a bank account and transferred using electronic means of payment".

The development of new technologies and the information environment has given rise to a phenomenon that has the same electronic digital form of its existence as e-money funds, usually referred to as "virtual currency", "digital currency", "cryptocurrency", "digital money".

The new edition of the European Central Bank report, prepared in February 2015, provides the following definition of virtual currency, "A digital representation of value not issued by a central bank, a credit institution or an e-money issuer, which can under certain circumstances serve as an alternative to money." This definition, according to A.I. Savel'ev, suggests that "at present, the European Central Bank does not consider 
virtual currency either as cash (the economic aspect) or as a means of payment (the legal aspect)" (Savel'ev, 2016).

This phenomenon, which does not exist for Russian legislation, has become widespread in our country. An attempt to legalize the actual existing phenomenon was made in Bill No. 424632-7 "On Amendments to Parts One, Two and Four of the Civil Code of the Russian Federation", submitted to the State Duma and adopted on the first reading on May 22, 2018. It proposed to introduce and define the new object of civil rights that is "digital money", which includes cryptocurrency as a certain set of electronic data (digital code or designation) created in a decentralized information system that does not certify the right to any object of civil rights that are not recognized by legal means of payment, but can be used by the clients of this system to make payments (Article 141.2 of the Bill). The specified bill did not define the location of this object in the system of civil rights objects, but provided that its turnover is carried out according to the rules on digital rights, which in turn are classified as property rights. At the same time, in Article 307 of the Civil Code of the Russian Federation, "Currency of Monetary Obligations", they were suggested to be indicated in the category of conditional monetary units, which would allow using digital money as a means of payment for a product, work or service.

During the discussion, the reference to digital money and cryptocurrency was excluded from the Bill. By the decision of the Council of the State Duma of the Russian Federation of December 17, 2018, the consideration of Bill No. 424632-7 was postponed "to a later date". According to Anatoly Aksakov, one of the co-authors of the bill and the head of the State Duma Committee on the Financial Market, digital money and cryptocurrency will be regulated under the concept of "digital law". The main regulatory act will be the Law "On Digital Financial Assets", which will define "digital rights". The draft of the mentioned law No. 419059-7 was adopted by the State Duma in the first reading. It proposes a very vague concept of "digital financial asset" as "electronic property created using cryptographic means", referring cryptocurrency, tokens to it, and expressly providing that digital financial assets are not legal means of payment in the Russian Federation.

The state of the legislative process does not eliminate the need to identify the ratio of "digital money" and e-money funds. The researchers note the obvious similarity of these phenomena, which manifests itself in a purely electronic-digital form of existence; accounting without using a bank account; using "as a cash equivalent" (Savel'ev, 2017: 136-153). It is not by chance that there is a qualification of cryptocurrency (Bitcoin, 
Litecoin) as e-money means in the domestic judicial practice (Definition of Commercial Court, Definition of Commercial Court of the Vologda Region dated August 15, 2016 in case No. A13-15648/2015; Definition of Commercial Court of the Moscow Region dated December 19, 2016 in Case No. A41-94274/15). However, this approach ignores the significant differences that characterize them: cryptocurrency units are not nominated in the currency of any state, i.e. they have no nominal value, while behind e-money funds are the funds that are provided for the operator's use; cryptocurrency has a special mechanism of occurrence, which is characterized as decentralized emission (Tsindeliani, Nigmatulina, 2018: 18-25); in contrast to e-money funds, cryptocurrency does not constitute a right of claim to a specific person, the right to a specific object, does not exist as an object of obligation relations. Therefore, the understanding that cryptocurrency does not apply to e-money funds, is not a form of their existence, prevails in the domestic doctrine. This does not exclude the presence of the opposite approach, supporters of which, based on the well-known similarity of e-money funds and cryptocurrency, consider it possible to extend the legal regime of e-money funds to the latter (Kucherov, 2018: 5-8). However, the aforementioned "digital" bills do not imply the application of the NPS Law to cryptocurrency and do not affect the legal status of e-money funds.

The unity of the functions performed allows some authors to declare that e-money funds belong to non-cash funds, "despite the fact that ... they are taken into account without a bank account and without concluding a bank account agreement. The balance of e-money funds (BEMF) recorded in the intrabank account, under the legal regime and in the range of the settlement operations performed with its help, does not practically differ from the funds recorded in the bank account" (Yefimova, 2017).

However, most authors consider this conclusion premature. Recognizing the closeness of the "property right of claim of their owner to the operator for issuing a certain amount of cash or non-cash money ... to the client's right of claim to the bank" (Savel'ev, 2016), A.I. Savel'ev draws attention to the key differences of the objects in question regarding the possibility of using their payment property without prior agreement with the lender, "Payments by electronic money are possible at this stage of their development only to the extent, in which the participants in the main legal relationship expressed their consent to its use. ... Its use is purely voluntary and involves a number of significant restrictions ... Thus, at this stage of development and regulation of electronic money in Russia it is impossible to recognize it as legal means of cashless payment" (Savel'ev, 2016). 
Views on the prospects for resolving this issue are different: from recognizing the need for legal reform, declaring e-money a legal means of payment in order to increase the "informatization of economic turnover" (Kazachenok, 2017: 47-50), or the call to wait for participants, regulators and infrastructure to "mature" (Savel'ev, 2016; Karnushin, 2017: 22-26), before denying e-money funds' belonging to money, declaring them quasi-monetary units, which are "conventional units for recording obligations under electronic payment services", which "can not be qualified as an object of monetary obligation" (Voronkov, 2018: 99-105).

Currently, the State Duma is considering two bills on amending the NPS Law: Draft federal law No. 603170-7 and Draft federal law No. 603192-7, which are planned to be considered in February-March 2019. Projected amendments to the NPS Law are aimed at developing NPS by involving new participants in the payment process in its scope of action and strengthening control over payments by the Bank of Russia. However, they do not affect the definition of the concept of e-money funds, do not eliminate the gap in solving the issue of their relationship to legal means of payment. At the same time, the issues of organization of monetary circulation, the establishment of money existence forms, the determination of the carrier of a legal tender status "is in its essence a public law element in the regulation of the monetary sphere" (Bashkatov, 2006). It was emphasized by the Government of the Russian Federation in its Official Response to Bill No. 424632-7, which stated that the issue of determining a particular object as a legal tender could not be resolved within the framework of civil law. Accordingly, the solution to this problem should be proposed not in the norms of the Civil Code of the Russian Federation on objects of civil rights, but in special federal laws relating to public law, possibly in the NPS Law.

\section{Part 2. The impact of the digital environment on the content of civil law subject category}

In addition to the change in existing approaches to the objects of civil legal relations, there is a transformation of existing ideas about their subjects, as a result of which the traditional definition of this civil legal category becomes ineffective. This situation is due to the specificity of the environment in which various actors are involved, and it is the peculiarities of the Internet that predetermine the processes taking place.

The identification of the specificity of the phenomenon under consideration depends on the solution of the issue regarding its nature, according to which two main approaches have emerged in the modern literature. The proponents of the first 
one believe that there is a concept in international law that allows recognizing an individual's independent right to the Internet. The basis for such a solution was the "report of the UN Special Rapporteur on the promotion and protection of the right to freedom of opinion and expression of Frank La Rue dated August 10, 2011, which states that "although Internet connectivity is not yet recognized as a human right, there is an obligation for states to promote the right to freedom of expression through the Internet." In addition, he drew attention to the fact that access to the Internet is necessary for the exercise of other rights, in particular the right to education, the right to participate in social, cultural, political life, as well as freedom of association and assembly" (Shatilina, 2018: 38 -39).

According to representatives of the opposite approach, there are no sufficient grounds for recognizing an independent right to the Internet, since the latter is only "a tool through which other rights are realized. The "father" of the Internet Vinton Cerf sticks to this position, believing that the Internet is not an end in itself, but an ordinary tool that makes life much more convenient, but nothing more. Other rights that we usually exercise offline are exercised through the Internet" (Gulyaev, 2018: 29-30).

The second approach to the issue regarding the nature of the Internet seems to be more promising, since the value of this phenomenon lies directly in the technical capabilities it provides to the user. It is the means of working with information in the broad sense of the word, including in the form of technical devices, software, etc., that attract subjects and allow them to exercise various rights, satisfy interests and pursue other goals. In this sense, in its most general form, the Internet is an effective means of "locating (providing), storing, searching, accessing, processing and using information provided in the form of electromagnetic signals (digital form)" (Belov, 2018: 260-261).

The wide spread of the Internet caused the creation of the so-called "virtual reality", i.e. special non-material information environment, within which various subjects can operate (providers, site owners, members of social networks, users, etc.) who are in a wide variety of relationships. As a result, relations on the Internet and their participants have become the subject of numerous studies, however, in most cases, the attention of scientists is focused on identifying the specificity of subjects of Internet relations through the prism of their rights and obligations. In this sense, the determination of the subject status directly depends on the qualification of the relations in which the subject is included. In particular, depending on the function performed, it is proposed to allocate "users; telecom operators; service providers providing access to the Network; host providers who provide disk space on their server to customers for a fee, as well 
as other basic Internet services; developers of cross-border information networks and network technologies; specialists" (Rassolov, 2009).

At the same time, such an approach does not reveal the specificity of the relations studied and the subjects involved in them, since it reflects only the functional purpose of the latter, but does not answer the question of whether there are qualitative, attributive differences between the persons acquiring rights and obligations in real life, real activities, and persons operating in the field of information technology.

Therefore, it is preferable to use a different approach, within the framework of which a single feature is proposed, which allows speaking about the specific position of subjects operating in the Internet environment. Thus, Professor V.A. Belov identified the Internet attributive feature, which "predetermines all the legal consequences caused by its existence and exploitation - this is an indefinite circle of people who can work with legally relevant and / or protected information ... In fact, it means the beginning of a new, unprecedented subject of private law - an indefinite circle of persons or (a little more substantively) each and everyone. The Internet has done what was previously possible only hypothetically: it provided a real opportunity to perform legally significant actions by any person we are interested in - in relation to each and everyone, and each and everyone - in relation to any interested person" (Belov, 2018: 261).

As a result, participants in relations connected with the use of information resources are characterized by the following properties: unlimitedness of their composition; a high degree of anonymity; extraterritoriality of action; self-management and selforganization.

At the same time, the unlimitedness (uncertainty) of the composition is understood not in an absolute sense, because essentially the ability to use information resources is finite, since it depends on the technical possibility to connect to the network. But in comparison with other means of communication, the Internet is a monopolist and only technical difficulties of the user can prevent them from using the resources provided by the network.

Anonymity is also a characteristic property, since the IP address of the technical device from which the Internet is accessed can be the only criterion that individualizes the user to a greater or lesser extent. No other characteristics, including those provided by the user during the registration of e-mail, in social networks and in other situations, do not allow establishing the legal identity of the subject. At the same time, the IP address is not universal, since it determines only the technical device itself connected 
to the Internet, but does not establish a specific user who at a certain point in time logged on to the system and performed certain actions. Moreover, one IP-address can be used by several persons, which allows the latter to remain anonymous subjects of relations.

The situation is further aggravated by the fact that, in contrast to real, actual relations, Internet communications are not strictly linked to the place and time of action, are extraterritorial in nature, and allow an unlimited number of people in different parts of the world to perceive certain information and respond to it simultaneously. Accordingly, familiar ideas about who is the subject of legal relations arising through the use of information technologies do not allow for the effective regulation of such relations, since the mechanism of civil law rules is based on a fundamentally different basis, suggesting the possibility of accurate determining the carrier of specific rights and obligations.

To get out of the current situation, the idea of the existence of a "virtual personality" formed in the sphere of virtual reality and often not coinciding with the real subject of social relations is increasingly expressed in modern literature. A virtual person is proposed to mean "a virtual body, a name (nickname), a set of certain characteristics, which together represent the virtual status of an individual" (Perchatkina et al., 2012: 16). At the same time, researchers express concern regarding the thinning of the boundaries between the virtual and real personalities of the subject, which makes it impossible to properly identify a person actively functioning in the Internet space with the real subject behind them. In particular, this state of affairs becomes relevant in connection with the growing distribution of Internet transactions regarding the alienation of created virtual identity (username) in games, social networks, online communities, etc. made by one user in favor of another.

As a result, the allocation of three types of subjects of civil relations, which may be individuals, legal entities and public legal entities with legal identity, which is typical for civil law, does not work with the participation of these entities in relations using Internet resources, and accordingly, civil law norms cannot be effectively used to resolve conflicts that arise.

This is particularly pronounced in relation to such subjects of civil law as the state and other public law entities. Modern society imposes strict requirements on the state and its officials, including those related to ensuring openness, transparency and accessibility of information relating to the activities of public legal entities. The first persons of the state actively use the Internet space, have accounts in social networks, 
regularly express their own point of view, participate in disputes and "are widely known". Accordingly, a serious question arises: Is the position taken by the head or another public person of the state on the Internet regarding public issues the position of the state, or is this personal opinion of a particular individual, and what criterion should be used to distinguish between such cases? As a consequence, how much can you be sure that the virtual personality of a state public person is a real one who keeps the account and expresses ideas there?

The current Russian civil legislation does not allow giving adequate answers to the questions posed. Thus, in accordance with Paragraph 2, Clause 2, Article 2 of the Civil Code of the Russian Federation, citizens and legal entities are involved in regulated by civil law. The Russian Federation, the subjects of the Russian Federation and the municipalities may also participate in relations regulated by civil law.

According to Article 124 of the Civil Code of the Russian Federation, public formations act in civil relations on an equal basis with other participants of these relations. The norms defining the participation of legal entities in relations regulated by civil law are applied to the specified subjects of civil law, unless otherwise appears in law and the characteristics of these subjects.

The procedure for the participation of public entities in relations regulated by civil law is fixed in Article 125 of the Civil Code of the Russian Federation. At the same time, Paragraph 1 and Paragraph 3 of Article 125 of the Civil Code of the Russian Federation include two different rules.

Thus, according to Paragraph 1 of Article 125 of the Civil Code of the Russian Federation, public authorities can act on behalf of public entities, by their actions, they can acquire and exercise property and personal non-property rights and obligations and appear in court within their competence established by acts determining the status of these authorities. This implies that only public authorities can speak directly on behalf of public entities, and the right of such an authority to appear on behalf of the state should be provided for in the act determining its status and comply with its competence.

In contrast to Paragraph 1, Clause 3 of Article 125 of the Civil Code of the Russian Federation establishes a different rule: in cases and procedures provided for by regulatory acts of public entities (federal laws, Decrees of the President of the Russian Federation, Decrees of the Government of the Russian Federation, regulatory acts of constituent entities of the Russian Federation), state bodies, as well as legal entities and citizens can act on their behalf on their special instructions. This means, a number of 
conditions must be observed in addition to those specified in Paragraph 1 of Article 125 of the Civil Code of the Russian Federation to participate in civil relations on behalf of public entities of other subjects. Namely, the regulations must include fixed cases and the order of such an appearance, there should be a special assignment made in relation to state bodies, legal entities and individuals.

Similarly, Paragraph 2 of Article 125 of the Civil Code of the Russian Federation resolved the issue of the procedure for the participation of municipalities in relations regulated by civil law, on behalf of which local authorities can acquire and exercise rights and obligations within their competence established by acts determining the status of these authorities.

As a result, according to Paragraph 1-2 of Article 125 of the Civil Code of the Russian Federation, as a general rule, the participation of the Russian Federation, constituent entities of the Russian Federation and municipalities in civil relations is carried out through the actions of state authorities and local governments; in the special cases provided for by Paragraph 3 of Article 125 of the Civil Code of the Russian Federation, if there is a special assignment, other entities, namely legal entities and individuals, may act on behalf of public entities.

The current Russian legislation does not contain norms, according to which individuals (heads of state or other officials) are authorized to participate in the Internet on behalf of the relevant public formation by keeping user accounts or expressing opinions on various issues that are important to society. Accordingly, the position taken by the first person of a state on a similar issue and expressed using Internet resources should be considered as a personal position of the corresponding individual.

However, exactly in this case the general rule defined by Article 125 of the Civil Code of the Russian Federation actually ceases to operate and, despite the absence of regulatory grounds, Internet users start to perceive the information provided by the first person of the state as official information provided by a competent and authorized subject, actively quote and use it. As a result, there is a paradox that has arisen at the junction of the legal field and the virtual reality that exists outside of it, which is impossible to ignore in modern conditions.

In fact, we are dealing with a virtual personality of a state or other public law formation, on behalf of which persons with such a degree of public recognition that allows users to identify them as a public law formation itself act in the Internet space. At the same time, the degree of connectedness of an individual and a public formation that it represents in the eyes of society is such that if this subject commits a tort, for 
example, due to the spread of information discrediting the honor, dignity and business reputation of the victim, or making offensive judgments, no one will have doubts that the responsibility should be placed on the state itself, whose representative allowed such judgments.

As P. Bourdieu rightly wrote, "the state is a well-founded illusion (fiction), a place that exists, in fact, precisely because it is considered to exist ... This mysterious thing exists due to its consequences and thanks to the collective belief in its existence, which is the basis of these consequences" (Bourdieu, 2017: 62). It is the collective faith that is the driving force in the virtual space, and it is the one that can empower a particular person who has social network accounts with the powers of a whole state.

It is impossible to exclude the reverse situation, when other, anonymous users, who have created accounts that can mislead users, act on behalf of the first person of the state or another official. In this case, the state and its representatives should be provided with adequate security features that can eliminate or minimize the negative consequences caused by the actions of third parties.

Unfortunately, the norms of current civil legislation are not able to solve the problems that arise effectively, since they are not designed for use in the digital reality. Solutions may vary from a complete ban on the participation of top state officials in the Internet segment to the development of a fundamentally new mechanism for civil law regulation of Internet relations involving public entities, but in any case the need for such transformations is already overdue and the issue requires adequate and timely resolution.

\section{References}

Arzumanova, L.L., Artemov, N.M., Boltinova, O.V. (2016). Aktual'nye problemy finansovogo prava [Current problems offinancial law]. Moscow, NORMA, INFRA-M, 208 p.

Bashkatov, M.L. (2006). Dogmaticheskaia konstruktsiia zakonnogo sredstva platezha [The dogmatic construction of a legal tender]. In Vestnik grazhdanskogo prava [Bulletin of civil law], 2, 42-64.

Belov, V.A. (2001). Singuliarnoe pravopreemstvo v obiazatel'stve [Singular succession in the obligation]. Moscow, Tsentr YurInfoR, 266 p.

Belov, V.A.(2018).Digital Private Law \& Rights: razmyshleniiaopreobrazovaniiakh, uzhe proizvedennykh v chastnom prave razvitiem global'noi komp'iuternoi seti Internet, i o reformakh, ego skoro i neminuemo po toi zhe prichine ozhidaiushchikh [Digital 
Private Law \& Rights: Reflections on Transformations, already made in private law by the development of Internet global computer network, and about reforms, which will soon and inevitably happen to it for the same reason]. In Pravo $v$ sfere Interneta: sbornik statei [Internet law: a collection of articles], 256-310.

Bourdieu, P. (2017). O gosudarstve: kurs lektsii v Kollezh de Frans (1989-1992) [On the state: a course of lectures at the Collège de France (1989-1992)]. Moscow, Izdatel'skii dom Delo, $720 \mathrm{p}$.

Gambarov, Iu.S. (1911). Kurs grazhdanskogo prava. T.I. Chast' obshch [Civil Law Course. Vol. 1. General part]. SPb, 780 p.

Gulyaev, K.S. (2018). Pravo cheloveka na Internet, prava v Internete i pri ispol'zovanii internet-veshchei: novye tendentsii [The human right to the Internet, rights on the Internet and using Internet things: new trends]. In Pretsedenty Evropeiskogo suda po pravam cheloveka [Precedents of the European Court of Human Rights], 1, 29-37.

Karnushin, V.E. (2017). Grazhdansko-pravovaia sushchnost' deneg kak ob"ektov grazhdanskikh prav [The civil legal nature of money as objects of civil rights]. In Iurist [Lawyer], 3, 22-26.

Kazachenok, O.P. (2017). Nesootvetstvie deistvuiushchego zakonodatel'stva potrebnostiam informatsionnogo obshchestva na primere dogovora zaima elektronnykh denezhnykh sredstv [The inconsistency of the current legislation with the needs of the information society through the example of an electronic money loan agreement]. In Zakony Rossii: opyt, analiz, praktika [Laws of Russia: Experience, Analysis, Practice], 10, 47-50.

Khrustaleva, A.V. (2016). Elektronnye denezhnyye sredstva v Rossiiskoi Federatsii i Evropeiskom soiuze [Electronic cash in the Russian Federation and the European Union]. In Bankovskoe pravo [Banking law], 3, 55-62.

Kucherov, I.I. (2018). Kriptovaliuta kak platezhnoe sredstvo [Cryptocurrency as a means of payment]. In Finansovie pravo [Financial law], 7, 5-8.

Lapach, L. (2003). Ponyatiye «imushchestvo» v rossiiskom prave i v Konventsii o zashchite prav cheloveka i osnovnykh svobod [The concept of "property" in Russian law and in the Convention for the Protection of Human Rights and Fundamental Freedoms]. In Rossiiskaia iustitsiia [Russian Justice], 1, 18-20.

Maksurov, A.A. (2018). Kriptovaliuta kak ekonomiko-pravovaia kategoriia [Cryptocurrency as an economic and legal category]. In Sovremennoe parvo [Modern Law], 9, 68-71. 
Novoselova, L.A. (2003). Protsenty po denezhnym obiazatel'stvam [Interest on monetary obligations]. Moscow, Statut, $192 \mathrm{p}$.

Perchatkina, S.A., Cheremisinova, M.Ye., Tsirin, A.M., Tsirina, M.A., Tsomartova, F.V. (2012). Sotsial'nye internet-seti: pravovye aspekty [Social Internet Networks: Legal Aspects]. In Zhurnal rossiiskogo prava [Journal of Russian Law], 5, 14-24.

Pokrovsky, I.A. (2003). Osnovnye problemy grazhdanskogo prava [The main problems of civil law], Moscow, Statut, $351 \mathrm{p}$.

Rassolov, I.M (2009). Pravo i Internet. Teoreticheskie problemy [Right and the Internet. Theoretical problems]. Moscow, Norma, 384 p.

Savel'ev, A.I. (2016). Elektronnaia kommertsiia v Rossii i za rubezhom: pravovoe regulirovanie [Electronic commerce in Russia and abroad: legal regulation]. Moscow, Statut, 640 p.

Savel'ev, A.I. (2017) Kriptovaliuty v sisteme ob"ektov grazhdanskikh prav [Cryptocurrencies in the system of civil rights]. In Zakon [Law], 8, 136-153.

Shatilina, A.S. (2018). Prava cheloveka v Internete: problema priznania prava na dostup $\mathrm{k}$ Internetu [Human rights on the Internet: the challenge of recognizing the right to access the Internet]. In Pretsedenty Evropeiskogo suda po pravam cheloveka [Precedents of the European Court of Human Rights], 1, 38-45.

Sukhanov, E.A. (2006). Grazhdanskoe pravo. V 4 t. T. I: Obshchaia chast' [Civil law. In 4 Vol. Vol. I: General part]. Moscow, Volters Kluver, 720 p.

Tsindeliani, I.A., Nigmatulina, L.B. (2018). Kriptovaliuta kak ob”ekt grazhdanskopravovogo i finansovo-pravovogo regulirovaniia [Cryptocurrency as an object of civil, financial and legal regulation]. In Finansovoe pravo [Financial Law], 7, 18-25.

Voronkov, N.S. (2018). Den'gi kak ob'ekt obiazatel'stv v mezhdunarodnom chastnom prave [Money as an object of obligations in international private law]. In Zakony Rossii: opyt, analiz, praktika [Laws of Russia: experience, analysis, practice], 8, 99-105.

Yakovlev, A.S. (2005). Imushchestvennye prava kak ob"ekty grazhdanskikh pravootnoshenii: Teoriia i praktika [Property rights as objects of civil legal relations: Theory and practice]. Moscow, Os'-89, $192 \mathrm{p}$.

Yefimova, L.G. (2017). Dogovor o vydache i ispol'zovanii bankovskoi karty $i$ dogovor ekvairinga $v$ sisteme dogovorov ob organizatsii beznalichnykh raschetov [Bank card issuance and use agreement and acquiring agreement in the system of agreements on the organization of cashless payments]. Moscow, Prospekt, $232 \mathrm{p}$. 


\title{
Некоторые проблемы влияния цифровой среды \\ на содержание категорий объекта \\ и субъекта гражданского права
}

\author{
И.Д. Кузьмина (часть 1), \\ И.С. Богданова (часть 2) \\ Сибирский федеральный университет \\ Россия, 660041, Красноярск, пр. Свободный, 79
}

Статья посвящена исследованию проблем, возникающих в результате воздействия современной циифровой среды на такие традиционные категории гражданского права, как объект и субъект правоотношений. В результате происходящих процессов ичифровизации общественных отночений в действующем законодательстве появилось специфическое средство платежа - электронные денежные средства, вопрос о природе которых остался законодателем не разрешенным. Анализ существующих подходов позволил прийти к выводу о том, что в доктрине электронные денежные средства обыкновенно квалифицируются как вид обязательственного денежного права требования, выраженного в электронной форме. Они являются самостоятельными объектами гражданских прав, не совпадающими с безналичными денежными средствами и с «циирровыми деньгами» (криптовалютами). Кроме того, в статье сделан вывод о том, что, помимо изменения существующих подходов к объектам гражданских правоотношений, в результате воздействия интернет-среды происходит трансформация и сложивщихся представлений об их субъектах, вследствие чего принятое определение данной гражданско-правовой категории становится неэффективным. Утверждается, что в интернет-пространстве функиионируют субъекты, обладающуие специфическими качествами: неограниченностью их состава, высокой степенью анонимности, экстерриториальностью действий, самоуправляемостью и самоорганизацией. Эти особенности не позволяют эффективно использовать нормь гражданского законодательства для разрешения возникающих коллизий. Возникающче сложности рассмотрены на примере участия публично-правовых образований и их должностных лии в сети Интернет.

Ключевые слова: иифровая среда, ресурсы сети Интернет, электронныле денежные средства, безналичные денежные средства, иифровые деньги, криптовалюта, виртуальная личность, субъект права в сети Интернет, публичные образования, глава государства.

Научная специальность: 12.00.00 - юридические науки. 